\title{
Host use in Orgyia trigotephras (Erebidae, Lymantriinae) during outbreak: effects on larval performance and egg predation
}

\author{
Olfa Ezzine $^{1,5}$ - Manuela Branco ${ }^{2}$ - Claire Villemant ${ }^{3}$ - Stefan Schmidt ${ }^{4}$. \\ Said Nouira $^{5}$ - Mohamed Lahbib Ben Jamâa ${ }^{1}$
}

Received: 16 January 2015 / Accepted: 26 March 2015 / Published online: 17 April 2015

(C) INRA and Springer-Verlag France 2015

\begin{abstract}
- Key message During outbreak, a discrepancy between larval performance and the main host used for egg laying was found in Orgyia trigotephras. It results mostly from intraspecific competition, but reduced egg mortality on the less suitable host plant may play a secondary role.

- Context Host range of polyphagous herbivores often comprises plants of low nutritional quality, which may however provide other benefits to the animal. Understanding the effect of host plants use on insect fitness and its population dynamics are central questions in insect-plant ecology. O. trigotephras Boisduval is a polyphagous Mediterranean defoliator. During
\end{abstract}

\section{Handling Editor: Aurelien Salle}

Contribution of co-authors Olfa EZZINE: project design, field and laboratory data collection, data analysis, and paper writing.

Manuela BRANCO: project design, data analysis, and paper writing. Claire VILLEMANT and Stefan SCHMIDT: data analysis and paper writing.

Said NOUIRA and Mohamed Lahbib BEN JAMÂA: supervisors.

Electronic supplementary material The online version of this article (doi:10.1007/s13595-015-0484-7) contains supplementary material, which is available to authorized users.

Olfa Ezzine

olfa.ezzine@gmail.com

Manuela Branco

mrbranco@isa.ulisboa.pt

Claire Villemant

villeman@mnhn.fr

Stefan Schmidt

hymenoptera.zsm@gmail.com

Said Nouira

saidnouira.ecologie@gmail.com

Mohamed Lahbib Ben Jamâa

benjamaaml@gmail.com outbreaks, larvae are frequently found on two unrelated host species, Pistacia lentiscus L. and Quercus coccifera L.

- Aim The aim of this study was to clarify the effect of population density on host use and the effects of host tree on insect performance.

- Methods The realized fecundity and egg mortality were measured during 3 years showing different population levels of the defoliator. Larval performance on the two host species was analyzed.

- Results Larvae fed on Q. coccifera had faster development, lower mortality, higher female/male ratio, and higher fecundity than larvae fed on P. lentiscus. Yet, at high population densities, under high intraspecific competition, $P$. lentiscus was the most used for egg laying. During outbreak, higher levels of parasitism by Aprostocetus sp. and predation by Coccidiphila rungsella $\mathrm{Nel}$ and Brusseaux were found on eggs laid on $Q$. coccifera compared to those laid on P. lentiscus.

- Conclusions The results indicate a discrepancy between host use and larvae performance, possibly ruled by resources exploitation and intraspecific competition. The reduced egg

1 Laboratoire de Gestion et de Valorisation des Ressources Forestières, National Institute for Research in Rural Engineering, Water and Forest (INRGREF), Bp 10, 2080 Ariana, Tunisia

2 Instituto Superior de Agronomia, Forest Research Center (CEF), Universidade de Lisboa, Tapada da Ajuda, 1349-017 Lisboa, Portugal

CP50, Entomologie. Muséum National d'Histoire Naturelle, ISYEB UMR7205 MNHN-CNRS, 45 rue Buffon, 75005 Paris, France

4 SNSB-Zoologische Staatssammlung München (ZSM), Münchhausenstr. 21, 81247 Munich, Germany

5 Faculté des Sciences de Tunis, Campus Universitaire, 1002, El Manar, Tunis, Tunisia 
predation on $P$. lentiscus during outbreaks might also provide an indirect benefit to the insect.

Keywords Competition · Predator · Parasitoid - Oviposition · Pistacia $\cdot$ Quercus

\section{Introduction}

Host plant use is a key element in the ecology and evolution of phytophagous insects (Thompson 1988). The life-history strategy of the respective herbivore species can affect the relationship between host plant use and insect performance with consequences on its population dynamics. In most species, host selection is made by gravid females when choosing a plant for oviposition, whereas the larvae have low mobility and are unable to seek actively for appropriate host plants (Thompson and Pellmyr 1991). Host-plant selection by phytophagous insects is largely determined by adult insects choosing the developmental location of offspring (Mayhew 1997) or "ecological fitting" (Agosta 2006). Generally, the egg-laying site coincides with the best food availability for larval development (Thompson and Pellmyr 1991). Jaenike (1990) showed that traditional models of optimal diet breadth in insects focus on insects in a steady state condition and ask what behavior will maximize the product of an individual's realized fecundity per unit time and expected fitness of offspring. Yet, phytophagous insects may select plants or plant parts not only based upon nutritional content, but also on other selective forces, such as the intensity of predation and parasitism (Bernays and Graham 1988). Still, in some species with very mobile larvae, such as in the case of Orgyia trigotephras, selective pressure imposed by plant nutritional value might not act as strongly as in species with less mobile larvae. O. trigotephras is distributed all over the Mediterranean Basin, from Anatolia (Patočka and Turčáni 2008) to southwestern Europe, France (Berard et al. 2010), Spain (Montoya and Masmano 1993), and North Africa (Villemant and Fraval 1993). Its populations usually show low densities relative to those of other lymantriid oak defoliators such as Lymantria dispar and Euproctis chrysorrhoea (Villemant and Fraval 1993; Chakali et al. 2002). Yet, in north-eastern Tunisia (Jebel Abderrahmane), the populations of O. trigotephras attained such high densities during the outbreak peak in 2005 and in the following years that cause complete defoliation of more than 500 ha of evergreen shrubs in Mediterranean forest. This situation led to serious concern for the conservation of the Mediterranean vegetation specific to this region. Although generally found at low densities, severe outbreaks of O. trigotephras occurred recently in Tunisia in 2005 (Ezzine et al. 2010) and in Italy in 2009 (Bella et al. 2011). During outbreak, our field observations in north-eastern Tunisia suggested an interesting pattern of host use by this defoliator, which concentrates its egg-laying and feeding activity on two unrelated host species, Q. coccifera and Pistacia lentiscus L. (Ezzine et al. 2010). The two tree species belong to phylogenetically distant plant families, Fagaceae and Anacardiaceae, respectively. A similar pattern was observed in southern Italy, where the larvae were found mainly on $P$. lentiscus during an outbreak period. Other plant species in these Mediterranean ecosystems, e.g., Erica multiflora L. and Erica arborea L., are also attacked, but to a much lower extent (Ezzine et al. 2014a, 2014b).

In Tunisia, O. trigotephras is bivoltine, with a spring generation from April to June and an autumn generation from October to December (Ezzine et al. 2014a). The females are apterous, whereas the males are winged. The female moth spends her brief life attached to her pupal cocoon which is spun by the larva between two or three leaves of the host tree. Mating and egg laying thus take place in the cocoon on the host plant on which the female pupate (Favard 1962). Up to 140 eggs are deposited in a compact egg mass covered with scales from the female's abdomen. Therefore, the host tree on which the late larval instars have fed becomes the place of oviposition. The high mobility of the larvae allows them to feed on different host plants over the course of the larval stages. First-instar larvae may disperse by ballooning as in other lymantriids (Zlotina et al. 1999); older larvae are able to walk as single individuals quickly to other plants.

From our field observations, we hypothesized that intraspecific competition as well as natural enemies may play important roles affecting the interaction between this polyphagous insect and the host plants used by the larvae, with implications on its fitness and population dynamics. We combined field data and laboratory experiments, in order to seek whether O. trigotephras show differences in (i) number of egg masses per plant (ii) larval performance, expressed by larval development duration, larval mortality and adult fecundity, and (iii) egg mortality, between the two main host plant species (Q. coccifera and P. lentiscus), as well as whether (iv) host plant use changes with the insect population density. Our hypothesis is that intraspecific competition as well as natural enemies may play important roles affecting the interaction between this polyphagous insect and the host plants used by the larvae, with implications on its fitness and population dynamics.

\section{Materials and methods}

\subsection{Study area}

The study took place in the Jebel Abderrahmane forest area in north-eastern Tunisia (Cap Bon) ( $36^{\circ} 51^{\prime} \mathrm{N}$ and $\left.10^{\circ} 47^{\prime} \mathrm{E}\right)$, at an altitude of $423 \mathrm{~m}$ a.s.l. The vegetation at the site consists of Mediterranean maquis with shrubs up to 1 to $2 \mathrm{~m}$ high. 


\subsection{Plant composition and densities}

Plant densities were investigated along two orthogonal line transects, approximately $280 \mathrm{~m}$ long. Each transect consisted of 12 plots (three plots in each cardinal direction) of $25 \mathrm{~m}^{2}$, according to shrubs analysis protocols (Wikum and Shanholtzer 1978). Plots were distant from one another by $50 \mathrm{~m}$. In each plot, we identified and enumerated all shrub species. Plant identification was carried out in 2005, 2009, and 2014 with the help of forest technicians and plant guides (Schoenenberger et al. 1971; DGF 1995). The largest and smallest diameters of the crown were measured and the mean diameter per tree was estimated.

In March 2009, plant densities assessment in each plot was established by dividing the number of trees from each species by the total area sampled.

\subsection{Egg mass density and plant defoliation}

Plant use for oviposition by $O$. trigotephras was evaluated with a field survey by counting the number of egg masses per plant on 30 Q. coccifera and 30 P. lentiscus individuals. The insects were collected at the end of their spring generation, in 2005, 2009, and 2014. Crown defoliation was assessed visually using six number classes (numbered 0-5), as follows: $(0)=0 \%$ defoliation; $(1)=1$ to $20 \% ;(2)=>20$ to $40 \% ;(3)=$ $>40$ to $60 \% ;(4)=>60$ to $80 \%$; $(5)=>80$ to $100 \%$ defoliation; the mid-point of the respective class was assigned to each plant in that category, respectively, $0,10,30,50,70$, and $90 \%$.

\subsection{Field egg masses, egg parasitism, and egg predation}

Thirty egg masses were collected in July of each study year (2005, 2009, and 2014), at the end of the moths' spring generation, on each host species and in the same area (about $300 \mathrm{~m}^{2}$ ). A total of $180 \mathrm{egg}$ masses were examined. Egg mass sampling was done along 300-m-long line transects, on plants distant from each other by at least $4.5 \mathrm{~m}$. Branches with egg masses were cut off with scissors and placed in plastic boxes ( $8 \mathrm{~cm}$ length $\times 3 \mathrm{~cm}$ width), which were kept in the laboratory at $25^{\circ} \mathrm{C}$ until parasitoids emerged.

To sort and count the different categories of eggs we used the method described by Villemant (1993). The silky cocoon was removed, and the egg mass was brushed through a 1-mmmesh strainer to remove the scale layer. Eggs were then placed in a Petri dish ( $9 \mathrm{~cm}$ in diameter) and observed under a binocular microscope (Leica, S42). Total number of eggs per egg mass was counted as an estimate of the realized fecundity. Eggs were further sorted and counted according to the following categories: (i) viable egg (with live embryo); (ii) hatched egg; (iii) parasitized egg, distinguished by the presence of a parasitoid exit hole: (iv) preyed egg, with distinct chorion fragments and traces of predator presence (larval skin, feces); (v) dried or brown egg containing a dry larva; (vi) unfertilized egg, characterized by the flat shape of a deflated balloon.

\subsection{Identification of parasitoids and predators}

Emerged adults of parasitoids were preserved with ethanol $(96 \%)$ in Eppendorf tubes $(1.5 \mathrm{ml})$; predator adults were killed with ether before morphological identification and DNA analysis. Morphological identification of the chalcidoid parasitoid was done at genus level using the Graham key (1987). Predator morphological identification was done, thanks to Patrice Leraut (MNHN, Paris).

DNA extraction, PCR, and sequencing were performed at the Canadian Centre for DNA Barcoding at the University of Guelph, Ontario (CCDB), following standard highthroughput protocols (Ivanova et al. 2006) available at http:// ccdb.ca/resources.php. DNA extracts are stored at the CCDB, with aliquots deposited in the DNA-Bank facility of the Zoologische Staatssammlung München (see http://www. zsm.mwn.de/dnabank/). Sequences and metadata are hosted in the Barcode of Life Data System (BOLD, http://www. boldsystems.org/, projects HTPOA "Hymenoptera of Tunisia-Parasitoids of Orgyia-" and INRGR "Global Geometridae/Lepidoptera of Tunisia-cork oak defoliatorsINRGREF-"). All sequences were also deposited in GenBank according to the International Barcode of Life Project (iBOL) data release policy. GenBank accession numbers are provided in Supplementary data S1.

For completing the identification of parasitoids and predators, we used a combined approach with molecular and morphological data.

\subsection{Laboratory feeding trials}

The offspring performance of $O$. trigotephras on the two host species was compared in laboratory feeding trials. Experiments were performed during April and May 2009, coinciding with the spring generation of $O$. trigotephras and with the budburst of host plants. Neonate larvae were obtained from eggs collected in the field in March 2009, and hatched in the laboratory. Larvae were reared on either $Q$. coccifera or $P$. lentiscus leaves in plastic boxes kept at $25 \pm 2{ }^{\circ} \mathrm{C}$ and a light regime of 12:12 L: D (light: dark) hours as in natural conditions. Foliage was collected biweekly in the study area $(5 \mathrm{~km}$ away from the study site during outbreak years) all along the rearing period and stored at $-4{ }^{\circ} \mathrm{C}$ during 4 days (until next leaf collection). Early instars larvae feed in group, consequently first and second instars larvae were reared in groups of 50 larvae/box (box size $16 \times 10 \times 10 \mathrm{~cm}$ ), later instars in groups of 20 larvae/box (box size $21 \times 10 \times 10 \mathrm{~cm}$ ), as described by Luciano (1995). Each larval instar was identified according to 
its morphological feature and was reared separately, by grouping freshly molted individuals and maintaining them until the next molt. The boxes were examined daily, and the number of molting larvae was recorded.

\subsection{Field feeding trials}

For each host species, three plants that showed no previous insect damage were selected and used for field rearing. An egg mass of about 80 to 120 eggs of $O$. trigotephras was placed on each plant, which plant was then covered with an insect-proof net $(70 \times 52 \mathrm{~cm})$, mesh size $0.5 \mathrm{~mm}$, to prevent larvae from escaping. Each plant had enough biomass to provide food for the complete larvae development. Inside the net, larvae could feed ad libitum. Rearing tests were done during the spring generation of $O$. trigotephras, at the beginning of April 2010 (non-outbreak year). After 10 weeks (development duration from egg hatch to adult female oviposition), tested plants were cut apart and brought to the laboratory for following examination. Dead larvae and pupae, live female and male adults, and egg masses were collected and counted from each plant.

\subsection{Statistical analysis}

Generalized linear models (GLMs) were applied to the following dependent variables: (1) number of egg masses per plant; (2) number of eggs per female (i.e., egg load); (3) number of eggs parasitized; and (4) number of predated eggs. Two explanatory categorical variables were tested: host species and year. The best distribution model was chosen according to the deviance to the degrees of freedom (df) criterion. A Poisson distribution model best fitted the egg load data (2). For the other variables, the Negative Binomial distribution model best fitted the data. Results are presented in the form of the Wald's chi-square test value $\left(\chi^{2}\right)$, parameter estimates and the respective $P$ value. Dispersion index $(\mathrm{DI}=\operatorname{Var}(\mathrm{X}) /$ Average $(\mathrm{X}))$ values were estimated for both parasitized and predated egg numbers. Correlations between these two variables and the egg mass were tested by Pearson correlation tests.

The proportion of dead larvae and pupae among the total individuals obtained in the feeding experiments was analyzed by GLM using a Binomial distribution model with log-link function, considering the factor plant species. The same procedure was used to analyse the sex ratio among emerged adults. Finally, the realized female fecundity was compared between the two host plant species using an independent sample $t$ test, after testing for normality and homogeneity of variance.

\section{Results}

\subsection{Plant communities and densities}

Thirteen plant species were identified (Table 1). Most abundant species were Cistus crispus L., Cistus villosus L. (Cistacea), two Ericaceae, E. arborea and E. multiflora, and Phillyrea media L. (Oleaceae). The two studied host plants P. lentiscus and Q. coccifera occurred at similar intermediate densities of about 11 plants per $100 \mathrm{~m}^{2}$ (Table 1). Other plant species occurred only rarely or with low constancy (according to the abundance classes' index of Braun-Blanquet 1932). Average crown diameter was $1.07 \mathrm{~m} \pm 0.15 \mathrm{~m}$ and $0.34 \mathrm{~m} \pm$ $0.03 \mathrm{~m}$, for $P$. lentiscus and Q. coccifera, respectively.

\subsection{Egg mass density and plant defoliation}

The numbers of $O$. trigotephras egg masses observed in the field were the highest in 2005 and the lowest in 2014 on both host plant species. In 2005 and 2009, when population density was high, the number of egg masses per plant was significantly higher on $P$. lentiscus than on $Q$. coccifera, with a greater difference between the two host species at the gradation peak in 2005 than later in 2009 (Table 2). In 2014, when population density was very low, the number of egg masses per plant was higher on $Q$. coccifera than on $P$. lentiscus, but the difference between host plants was not significant $(P=0.109)$. Overall, significant differences appeared between host species $\left(\chi^{2}{ }_{1}=\right.$ 5.129, $P=0.024)$ and years $\left(\chi_{2}^{2}=170.228, P<0.001\right)$, with a significant interaction $\left(\chi_{2}^{2}=17.947, P<0.001\right)$.

Plant crown defoliation in May 2005, during the peak of outbreak, averaged 60 and $90 \%$ for P. lentiscus and Q. coccifera, respectively. These levels sank to $27 \%$ on

Table 1 Average plant density $( \pm$ SE) per plant species in Jebel Abderrahmane maquis (Tunisia) in 2009, in 12 plots ( 3 plots in each cardinal direction) of $25 \mathrm{~m}^{2}$

\begin{tabular}{lc}
\hline Plant species & Density (plant/100 $\left.\mathrm{m}^{2}\right)$ \\
\hline Cistus crispus & $36.0 \pm 22.4$ \\
Phillyrea media & $23.3 \pm 5.0$ \\
Erica multiflora & $20.0 \pm 10.2$ \\
Cistus villosus & $17.3 \pm 16.2$ \\
Erica arborea & $13.3 \pm 9.9$ \\
Pistacia lentiscus & $11.3 \pm 3.6$ \\
Quercus coccifera & $10.7 \pm 6.8$ \\
Calicotome villosa & $4.3 \pm 2.8$ \\
Daphne gnidium & $2.0 \pm 1.8$ \\
Cistus monspeliensis & $1.7 \pm 2.3$ \\
Chamaerops humilis & $1.3 \pm 1.3$ \\
Ampelodesmos mauritanicus & $0.3 \pm 1.2$ \\
Pinus halepensis & $0.3 \pm 1.2$ \\
\hline
\end{tabular}


Table 2 Average number $( \pm \mathrm{SE})$, $n=30$, of egg masses of Orgyia trigotephras and of eggs per egg mass per plant species and year in Jebel Abderrahmane maquis (Tunisia)

\begin{tabular}{|c|c|c|c|c|}
\hline & \multirow[b]{2}{*}{ Host species } & \multicolumn{3}{|l|}{ Year } \\
\hline & & 2005 & 2009 & 2014 \\
\hline \multirow[t]{2}{*}{ Egg masses } & Pistacia lentiscus & $34.2 \pm 7.6^{\mathrm{a}}$ & $11.2 \pm 2.0^{\mathrm{a}}$ & $0.3 \pm 0.1^{\mathrm{a}}$ \\
\hline & Quercus coccifera & $7.4 \pm 0.9^{b}$ & $5.6 \pm 0.7^{\mathrm{b}}$ & $0.6 \pm 0.3^{\mathrm{a}}$ \\
\hline \multirow[t]{2}{*}{ Eggs per egg mass } & Pistacia lentiscus & $168 \pm 9.5^{\mathrm{a}}$ & $104.7 \pm 7.5^{\mathrm{a}}$ & $100.7 \pm 1.8^{\mathrm{a}}$ \\
\hline & Quercus coccifera & $150.4 \pm 14.3^{\mathrm{a}}$ & $66.4 \pm 7.3^{\mathrm{b}}$ & $92.1 \pm 1.8^{\mathrm{b}}$ \\
\hline
\end{tabular}

Within each year, values labeled with different superscript letters are significantly different $(P<0.05)$
P. lentiscus and $55 \%$ on Q. coccifera in May 2009. In April 2014, when the population was at low density, no defoliation was observed on $P$. lentiscus and only $5 \%$ defoliation was recorded on $Q$. coccifera.

\subsection{Field egg load}

The average egg load (number of eggs per egg mass) varied between host plants $\left(\chi_{1}^{2}=221.9, P<0.001\right)$ and among years $\left(\chi_{2}^{2}=1670.5, P<0.001\right)$; the interaction term was also significant $\left(\chi_{2}^{2}=115.5, P<0.001\right)$. In all years, egg load in the field was higher on $P$. lentiscus than on $Q$. coccifera (Table 2). For both host plant species, egg load was higher in 2005 (outbreak peak) in comparison to 2009 and 2014 (Table 2).

\subsection{Field parasitized and predated eggs}

The egg masses collected in the field were parasitized by only one species of the genus Aprostocetus (Hymenoptera, Eulophidae), which was not yet identified at species level. Eggs were also predated by the larvae of one lepidopteran species, C. rungsella $\mathrm{Nel}$ and Brusseaux, 1997 (Cosmopterigidae).

The dispersion index (DI) was well above 1.0 in all cases, evidencing an aggregation distribution pattern of parasitoid and predator attacks (Table 3 ) also consistent with the negative binomial distribution model. The GLM results show that the number of parasitized eggs significantly differed in relation to host plant species $\left(\chi_{1}^{2}=23.45, P<0.001\right)$ and year $\left(\chi_{2}^{2}=\right.$ 104.03, $P<0.001)$. Parasitism was significantly higher on Q. coccifera than on P. lentiscus in 2005 and in 2009 (Table 3). In 2014, however, the number of parasitized eggs did not differ in relation to host plant species $(P=0.236)$. The interaction term was significant for parasitized eggs $\left(\chi_{2}^{2}=\right.$ 6.81, $P=0.033)$ as well as for predated eggs $\left(\chi^{2}{ }_{1}=31.92\right.$, $P<0.001)$. In 2005 , no predated eggs were observed on $P$. lentiscus; in 2009 , egg predation was higher on Q. coccifera $(P<0.001)$, whereas in 2014 , an opposite trend was found with higher predation on $P$. lentiscus in comparison to $Q$. coccifera $(P=0.003)$.

The number of parasitized or predated eggs were not significantly correlated with egg load $\left(r^{2}=-0.058, P=0.442\right.$ and $\left.r^{2}=-0.037, P=0.625\right)$. Yet, the number of parasitized and predated eggs were correlated significantly $\left(r^{2}=0.318\right.$, $P<0.001)$.

\subsection{Larvae development in the laboratory}

In the laboratory experiment, total development time from hatching to adult emergence was almost twice as long on $P$. lentiscus (57.3 \pm 0.4 days) as on $Q$. coccifera (37.6 \pm 1.1 days) (Fig. 1). The effects of host plant species $\left(\chi^{2}{ }_{1}=\right.$ 137.8, $P<0.001)$ and duration of larval instars $\left(\chi^{2}{ }_{5}=1101.8\right.$, $P<0.001)$ were both significant, as was the interaction term $\left(\chi^{2}{ }_{5}=1101.8, P<0.001\right)$. The difference in the development times due to host plant species was significant only for the first and second instar. In later stages, the development times were similar on the two host species (Fig. 1).

\subsection{Larval and pupal survival, sex ratio, and fecundity in the field}

In the field experiment, larval and pupal mortalities were significantly higher on $P$. lentiscus than on $Q$. coccifera. The host species had a significant effect on the proportions of both dead larvae $\left(\chi_{1}^{2}=36.45, P<0.001\right)$ and dead pupae $\left(\chi_{1}^{2}=5.07, P=\right.$

Table 3 Average number ( \pm SE) of eggs, $n=30$, per egg mass of Orgyia trigotephras parasitized by Aprostocetus sp. and predated by Coccidiphila rungsella at Jebel Abderrahmane (Tunisia), and dispersion index values for the parasitoid/predator on the two host plant species

\begin{tabular}{lllll}
\hline \multicolumn{5}{c}{ Year } \\
\cline { 3 - 5 } & Host species & 2005 & 2009 & 2014 \\
\hline Parasitized egg & Pistacia lentiscus & $0.4 \pm 0.2^{\mathrm{a}}$ & $1.1 \pm 0.3^{\mathrm{a}}$ & $7.1 \pm 1.4^{\mathrm{a}}$ \\
& Quercus coccifera & $1.8 \pm 0.5^{\mathrm{b}}$ & $2.9 \pm 0.5^{\mathrm{b}}$ & $9.8 \pm 2.2^{\mathrm{a}}$ \\
\multirow{2}{*}{ Dispersion index } & Pistacia lentiscus & 2.2 & 2.3 & 8.5 \\
& Quercus coccifera & 4.3 & 2.20 & 15 \\
\multirow{2}{*}{ Predated egg } & Pistacia lentiscus & 0 & $1 \pm 0.2^{\mathrm{a}}$ & $5.2 \pm 1^{\mathrm{a}}$ \\
& Quercus coccifera & $0.3 \pm 0.2$ & $4.0 \pm 1.4^{\mathrm{b}}$ & $2.1 \pm 0.9^{\mathrm{b}}$ \\
Dispersion index & Pistacia lentiscus & - & 1.7 & 5.7 \\
& Quercus coccifera & 5.2 & 13.9 & 10.1 \\
\hline
\end{tabular}

Within each year, values labeled with different superscript letters are significantly different $(P<0.05)$ 


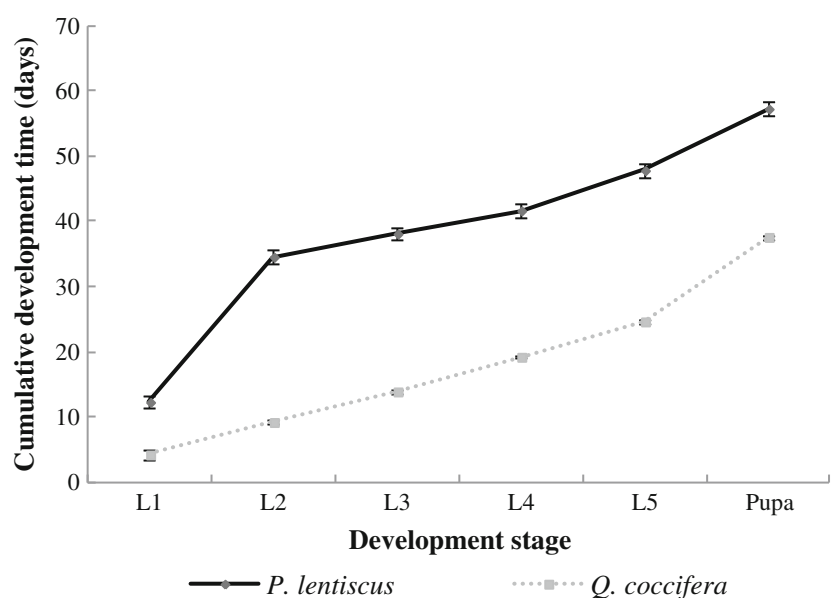

Fig. 1 Cumulative development time of Orgyia trigotephras in days (average \pm SE) from first (L1) to fifth larval instar (L5) and pupa

0.024). The relative risk of mortality ( $P_{\text {mortality on } P \text {. lentiscus }}$ $\left.P_{\text {mortality on } Q \text { coccifera }}\right)$ is about 39 times higher for larvae, and 67 times higher for pupae, for individuals fed on $P$. lentiscus compared to those fed on $Q$. coccifera.

Among individuals that reached adult stage, the proportion of females was higher on $Q$. coccifera $(0.46)$ than on P. lentiscus $(0.25) ;\left(\chi_{1}^{2}=4.76, P=0.029\right)$. After mating, realized fecundity, i.e., number of eggs oviposited, was significantly higher for individuals reared on $Q$. coccifera $(87 \pm 6.2$, $n=90)$ compared to those reared on $P$. lentiscus $(26.7 \pm 17.8$, $\mathrm{n}=6$ ); $t$-test $=-2.445, d f=94, P=0.016$. Equal variances were assumed $(F=0.620, P=0.433)$.

\section{Discussion}

Adult females of $O$. trigotephras are wingless, and egg laying occurs on the same plant on which the respective mature larva had fed. Therefore, plants used for oviposition should also be optimal from the nutritional point of view. Nevertheless, we could not establish a link between the host plant species used for oviposition and the larval performance. During outbreak years, in 2005 and 2009, egg masses were found more frequently on P. lentiscus, whereas larval survival, development, and adult fecundity were higher when larvae could feed on Q. coccifera leaves. These two results apparently contradict optimal foraging strategy predicted by many studies on the herbivore/plant interaction (Singer et al. 2004). Yet, insect preference for particular plant species might be subject to trade-offs imposed by selective forces other than nutritional quality (Videla et al. 2012). As an alternative explanation, we hypothesize that host use for oviposition by $O$. trigotephras is ruled by resources exploitation in function of densitydependent intraspecific competition. In years of high population density, most late-instar larvae move to P. lentiscus, possibly due to the previous high exploitation of $Q$. coccifera, notably by young instar larvae. In fact, levels of defoliation of $Q$. coccifera reached almost $100 \%$ during the outbreak peak while they were always lower for $P$. lentiscus. It has been shown that under high density populations, such as with exotic species in the absence of natural enemies, herbivorous insects can extend the realized host range and use less suitable hosts (e.g., Branco et al. 2014). Foraging theory also proposes that high intraspecific competition and scarce resources lead to increases in population diet range (Svanbäck and Bolnick 2007). An indirect negative effect will then occur at high densities, as usually insect fitness will be worst on marginal host plants. This is the case for $O$. trigotephras, since egg laying on $P$. lentiscus increases the mortality of young larvae and reduces adult fecundity. A negative density-dependent result on its population dynamics could then partially explain the decline of population on the following years.

At low population density, egg masses were present on $Q$. coccifera in slightly higher numbers than on P. lentiscus; still, egg densities on the two host plants species were not significantly different. Since overall larval performance is much lower on P. lentiscus, it is interesting to find that some larvae moved to this host plant even when populations were at low density and only $5 \%$ defoliation was observed on $Q$. coccifera. The larvae of $O$. trigotephras are very well able to move to the best food source. In the Mediterranean landscape system studied, plant communities are rich and composed mostly of mixed evergreen shrub species (e.g., Orshan 1983) as also indicated by our field surveys of the plant communities. Thus, it is very easy for the larvae to walk from one plant species to another, i.e., larvae can find a suitable oak plant to feed on, in alternative to $P$. lentiscus, when population densities are low, especially because both plant species occur at similar densities. Nevertheless, from our field observations $P$. lentiscus trees were on average larger than $Q$. coccifera which could have played a role in tree selection by the larvae.

Egg masses were not only more numerous on $P$. lentiscus during outbreak years, but also contained a higher number of eggs on this host species during the three studied years. Thus, female larvae with potential higher fecundity at the adult stage seem to be those exercising a higher selective use of P. lentiscus. Since female fecundity is generally proportional to larval food quality and body size (Hamilton and Lechowicz 1991; Tammaru et al. 2002), we may assume that wellnourished larvae could have a better mobility facilitating more active searching for the most appropriate host to spin the cocoon on.

Even if larvae may easily move to another plant, the egg laying on P. lentiscus, which is phylogenetically distant from the most suitable host plant species Quercus spp., is intriguing. Ezzine et al. (2014c) demonstrated that the best efficiency of conversion of ingested and digested food of $O$. trigotephras among five tested shrub species was for larvae reared on Q. coccifera. Still, whereas Q. coccifera foliage is of better 
quality for young larvae, once trees are defoliated, the quantity of available food becomes a more limiting factor. Mature larvae can compensate the quality of the food in a less suitable host by increasing ingestion of available foliage (White 2005). Other plant species occurring at higher densities in the studied area, such as some $C$. crispus, $C$. villosus, E. multiflora, and $P$. media were not used by $O$. trigotephras except episodically (Ezzine, pers. observ.).

Many studies have addressed the mechanisms of host plant selection by merely focusing on the plant-herbivore interaction (e.g., Price et al. 1980; Vallardes and Lawton 1991; Gripenberg et al. 2010). Yet, other selective pressures, namely natural enemies (Moon and Stiling 2006), intraspecific and interspecific competition may play further important roles concerning plant use by herbivores (Dixon 1998; Lill et al. 2002). For several phytophagous insects, it has been demonstrated that they may select plants or plant parts not only based upon nutritional content, but also on the intensity of predation and parasitism (Bernays and Graham 1988). Our data on egg mortality due to parasitoid and predator natural enemies also point that both, parasitism by Aprostocetus sp. and predation by $C$. rungsella were significantly higher on $Q$. coccifera than on P. lentiscus when populations were at high densities. Thus, the low nutritional quality of a host plant could be compensated by a positive indirect effect of a release from natural enemies. Similar selective pressures were found in other insect/plant systems. Feder (1995) showed that oviposition by the apple maggot, Rhagoletis pomonella, in its derived host (apple) provided a physical refuge for eggs, resulting in lower rates of parasitism than on the ancestral host (hawthorn). In the same way, the sphingid moth, Manduca sexta, oviposits preferentially on a less suitable host plant species to reduce mortality of eggs and larvae from natural enemies (Mira and Bernays 2002). Nevertheless, at low population density of $O$. trigotephras, parasitism was no longer significantly lower on $P$. lentiscus, and the numbers of predated eggs were even higher (though not significantly) on this host plant species. Therefore, the advantage of egg laying on P. lentiscus at low density becomes null, unless we consider the strategy of not "putting all eggs in one basket" in response to the observed aggregated pattern of the predated and parasitized eggs. Also, the mortality rates by natural enemies were very low on both host species.

During outbreak periods, oviposition by $O$. trigotephras seems to support the hypothesis that host use outcome is ruled by intraspecific competition due to resource exploitation acting in a density-dependent manner. Interspecific competition appears also to be important in the studied system, as in 2014, another defoliator, Anacampsis scintillela Fischer von Röslerstamm (Gelechiidae, Anacampsinae), was observed at Jebel Abderrahmane competing with $O$. trigotephras for Q. coccifera (Ezzine et al. 2014b). First instar larvae of $O$. trigotephras feed on fresh foliage of $Q$. coccifera (Ezzine et al. 2010) later than A. scintillela. If fresh foliage is already attacked by $A$. scintillela, neonate larvae of $O$. trigotephras will die by starvation. Therefore, the competition between $O$. trigotephras and A. scintillela for the same host plant may further influence the dynamics of one or both competitors (Ezzine et al. 2014b).

\section{Conclusion}

We conclude that host plant use by $O$. trigotephras and fitness is not merely nutritionally mediated. Intraspecific densitydependent competition as well as interspecific competition and natural enemies might be relevant to understand host plant use in this study system. The use of poor host species during outbreak years might lead to higher larval mortality and lower fecundity, but conversely, it may reduce egg mortality due to natural enemies and lessen intraspecific and interspecific competition. The consequences of these mechanisms on the population dynamics of $O$. trigotephras need to be investigated. Overall, these results highlight the complexity of mechanisms involving phytophagous insects regarding their host plant use, and the importance of simultaneous evaluation of the various driving forces involved in a multi-trophic context (Videla et al. 2012).

Acknowledgments Thanks to Patrice Leraut (Muséum National d'Histoire Naturelle, France) for his availability and contribution to the identification of the predator, and to Axel Hausmann (Zoologische Staatssammlung München) for his encouragement and for giving the first author the opportunity to do the molecular analysis. Thanks to Mabrouk Grami (CFAR, Tunisia) and forest technicians for their valuable help in the field, and to Paul Hebert and his lab (CCDB, Guelph, Canada) for conducting the DNA barcoding analysis.

Funding Funding provided to achieve the presented results was given from National Institute for Research in Rural Engineering, Water and Forest (INRGREF)

\section{References}

Agosta SJ (2006) On ecological fitting, plant-insect associations, herbivore host shifts, and host plant selection. Oikos 114:556-565. doi: 10.1111/j.2006.0030-1299.15025.x

Bella S, Longo S, Sidoti A (2011) Indagini su Teia trigotephras defogliatore del lentisco nella Sicilia sud orientale. Dissertation, Atti XXIII Congresso Nazionale Italiano di Entomologia

Berard R, Bordon J, Colomb C, Savourey M, Audibert C, Rozier Y, Clary J (2010) Les Macrohétérocères de la Région Rhône-Alpes. Cah Musée Confluences Etudes Sci 1:9-42

Bernays EA, Graham M (1988) On the evolution of host specificity in phytophagous arthropods. Ecology 69:886-892. doi:10.2307/ 1941237

Branco M, Dhahri S, Santos M, Ben Jamâa ML (2014) Biological control reduces herbivore's host range. Biol Control 69:59-64

Braun-Blanquet J (1932) Plant sociology. The study of plant communities. McGraw-Hill, New York 
Chakali G, Attal-Bedreddine A, Ouzani H (2002) Les insectes ravageurs des chênes, Quercus suber et Quercus ilex, en Algérie. IOBC/wprs Bull 25:93-100

de V Graham MWR (1987) A reclassification of the European Tetrastichinae (Hymenoptera: Eulophidae), with a revision of certain genera. Bull Br Mus Nat Hist (Ent) 55:1-392

DGF (1995) Forêt domaniale De Béni Oualid. Plan d'aménagement 1996-2015. Direction générale des forêts. CRDA de Nabeul SOGET Maghreb

Dixon AFG (1998) Aphid ecology: an optimization approach. Chapman and Hall, London

Ezzine O, Ben Jamâa ML, M'nara S, Nouira S (2010) Bioécologie d'Orgyia trigotephras (Boisduval, 1829), (Lepidoptera, Lymantriidae) à Jebel Abderrahmane (Nord Est, Tunisie). IOBC/wprs Bull 57:123-127

Ezzine O, Hausmann A, Branco M, Mannai Y, Dhahri S, Nouira S, Ben Jamâa MLB (2014a) Genetic patterns, host use and larval morphology in Tunisian populations of Orgyia trigotephras. Bull Insectology 67:73-79

Ezzine O, Hammami S, Dhahri S, Nouira S, Ben Jamâa ML (2014b) Did competition influence the bio ecological study of Anacampsis scintillela Fischer von Röslerstamm, 1841 (Lepidoptera: Gelechiidae Anacampsinae) in Tunisia? Proceedings of the MED INSECT 4. Antalya, Turkey:9-14 April. in SDU Fac For J (in press).

Ezzine O, Mannai Y, Nouira S, Ben Jamâa ML (2014c) Les indices nutritionnels d'Orgyia trigotephras Boisduval, 1829 (Lepidoptera, Lymantriidae) sur cinq espèces du maquis. IOBC/wprs Bull 101: 187-194

Favard P (1962) Contribution à l'étude de la faune entomologique du chêne vert en Provence. Thèse Fac Sci. Aix-Marsaille, Amboise

Feder JL (1995) The effects of parasitoids on sympatric host races of Rhagoletis pomonella (Diptera: Tephritidae). Ecology 76:801-813. doi:10.2307/1939346

Gripenberg S, Mayhew PJ, Parnell M, Roslin T (2010) A meta-analysis of preference performance relationships in phytophagous insects. Ecol Lett 13:383-393. doi:10.1111/j.1461-0248.2009.01433.x

Hamilton DJ, Lechowicz MJ (1991) Host effects on the development and fecundity of gypsy moth, Lymantria dispar L., reared under field conditions. Can J Zool 69:2217-2224. doi:10.1139/z91-309

Ivanova V, Dewaard JR, Hebert PDN (2006) An inexpensive, automation friendly protocol for recovering high quality DNA. Mol Ecol Notes 6:998-1002. doi:10.1111/j.1471-8286.2006.01428.x

Jaenike J (1990) Host specialization in phytophagous insects. Annu Rev Ecol Syst 21:243-273. doi:10.1146/annurev.es.21.110190.001331

Lill JT, Marquis RJ, Ricklefs RE (2002) Host plants influence parasitism of forest caterpillars. Nature 417:170-173. doi:10.1038/417170a

Luciano P (1995) Integrated protection in cork-oak forests. Proceedings of the IOBC study group meeting. OILB/SROP, Tempio Pausania

Mayhew PJ (1997) Adaptive patterns of host-plant selection by phytophagous insects. Oikos 79:417-428. doi:10.2307/3546884

Mira A, Bernays EA (2002) Trade-offs in host use by Manduca sexta: plant characters vs. natural enemies. Oikos 97:387-397

Montoya JAM, Masmano MB (1993) Una contribución al estudio de los insectos defoliadores de la encina $(Q$. ilex $\mathrm{L}$.) en el noroeste de la provincia de Albacete. Rev Fac Educ Albacete 8:281-288
Moon DC, Stiling P (2006) Trade-off in oviposition strategy: choosing poor quality host plants reduces mortality from natural enemies for a salt marsh planthopper. Ecol Entomol 31:236-241. doi:10.1111/j. 1365 2311.2006.00785.x

Orshan G (1983) Approaches to the definition of Mediterranean growth forms. In: Kruger FJ, Mitchell DT, Jarvis JUM (eds) Mediterranean type-ecosystems, 1st edn. Springer, Berlin, pp 86-100

Patočka J, Turčáni M (2008) Contribution to the description of pupae of the western Palaearctic lymantriids (Lepidoptera, Lymantriidae). Linz Biol Beitr 40:901-920

Price PW, Bouton CE, Gross P, McPheron BA, Thompson JN, Weis AE (1980) Interactions among three trophic levels: influence of plants on interactions between insect herbivores and natural enemies. Annu Rev Ecol Syst 11:41-65. doi:10.1146/annurev.es.11.110180. 000353

Schoenenberger A, Albert E, Dimanche P, Franclot A, Marion J (1971) Premiers enseignements des Arboretums Forestiers. Programme des Nations Unis pour le développement. Organisation des Nations Unies pour l'alimentation et l'agriculture. $178 \mathrm{p}$

Singer MS, Rodrigues D, Stireman JOI, Carriére Y (2004) Roles of food quality and enemy free space in host use by a generalist insect herbivore. Ecol 85:2747-2753. doi:10.1890/03-0827

Svanbäck R, Bolnick DI (2007) Intraspecific competition drives increased resource use diversity within a natural population. Proc R Soc B 274:839-844. doi:10.1098/rspb.2006.0198

Tammaru T, Esperk T, Castellanos I (2002) No evidence for costs of being large in females of Orgyia spp. (Lepidoptera, Lymantriidae): larger is always better. Oecologia 133:430-438. doi:10.1007/s00442 002 1057-7

Thompson JN (1988) Evolutionary ecology of the relationship between oviposition preference and performance of offspring in phytophagous insects. Entomol Exp Appl 47:3-14. doi:10.1111/j.1570 7458. 1988.tb02275.x

Thompson JN, Pellmyr O (1991) Evolution of oviposition behavior and host preference in Lepidoptera. Annu Rev Entomol 36:65-89. doi: 10.1146/annurev.en.36.010191.000433

Vallardes G, Lawton JH (1991) Host-plant selection in the holly leafminer: does mother know best? J Anim Ecol 60:227-240

Videla M, Valladares GR, Salvo A (2012) Choosing between good and better: optimal oviposition drives host plant selection when parents and offspring agree on best resources. Oecologia 169:743-751. doi: 10.1007/s00442-011-2231-6

Villemant C (1993) Les prédateurs démanteleurs des pontes de Porthetria dispar dans les subéraies marocaines. Thèse Univ, Orléans

Villemant C, Fraval A (1993) La faune entomologique du chêne-liège en forêt de la Mamora. Ecol Mediterr 19:89-98

White TCR (2005) Why does the world stay green? Nutrition and survival of plant-eaters. CSIRO Publishing, Coolingwood

Wikum DA, Shanholtzer GF (1978) Application of the Braun Blanquet cover abundance scale for vegetation analysis in land development studies. Environ Manag 2:323-329. doi:10.1007/BF01866672

Zlotina MA, Mastro VC, Elkinton JS, Leonard DE (1999) Dispersal tendencies of neonate larvae of Lymantria mathura and the Asian form of Lymantria dispar (Lepidoptera: Lymantriidae). Environ Entomol 28:240-245. doi:10.1093/ee/28.2.240 